\title{
EXAMINATION ON RISK MANAGEMENT ANALYSIS FOR CONSTRUCTION INDUSTRY
}

\author{
Moinuddin H \\ M.Tech. Degree in Construction Engineering and Project Management, \\ B.S.A. Crescent Institute of Science and Technology, Chennai, Tamilnadu, India

\section{Dr. K. Yogeswari} \\ Associate Professor, Department of Civil Engineering, \\ B.S.A. Crescent Institute of Science and Technology, Chennai, Tamilnadu, India
}

\begin{abstract}
Construction projects are intricate, uncertain \& risky that causes delay. Construction projects are facing several risks it will affect the project on schedule \& cost. Risk management is practiced in many industries. Many industries enable a risk management plan in their projects for better performance and profits. No project is free from risks. Projects from the construction industry are different in size which involves different types of risk. The project aims to identify the risk and provide the best solutions. Some of the risks determined in the project are defective design, financial issues, delay in permitting, availability of drawings, changes in codes \& drawing changes in the scope of work, payment delay, accidents during construction. We aim to identify risk management practices in the construction industry \& it helps to mitigate risk in construction industries
\end{abstract}

Keywords: Risk Management, Construction Industry

Cite this Article: Moinuddin H and K. Yogeswari, Examination on Risk Management Analysis for Construction Industry, International Journal of Civil Engineering and Technology (IJCIET), 12(5), 2021, pp. 37-43.

https://iaeme.com/Home/issue/IJCIET?Volume=12\&Issue $=5$

\section{INTRODUCTION}

\subsection{General}

The risk has become a part of our day to today life. One such area is the construction industry. Projects within the construction sector are categorized as fragmented, temporary \& complex which brings upon risk exposure. Risk can be described as the likelihood of an event multiplied by its extent. A risk management plan will aid a construction industry to consider the various risks before they happen and reduce their influence on the project. The benefits of risk management are to provide good labor conditions and to protects from events that will cause damage to both the company and the environment. 


\subsection{Strategies and Process}

Risk Management involves the procedure of conducting risk planning, risk identification, risk analysis, and observe risk on a project. Risk management aims to optimize time, cost, and quality

The Project Risk Management processes are:

Plan Risk Management- The risk management plan is important in the construction industry. It helps to optimize risk in construction projects. There are several tool and techniques to plan risk more efficiently that describes how risk `activities will be performed.

Identify Risks - Risk is identified based on practices in the construction industry so that project managers are listed out based on previous project experience. Based on the study we have identified some risks are defective design, financial issues, delay in permitting, availability of drawings, changes in codes \& drawing changes in the scope of work, payment delay, accidents during construction, and cost overrun in project

Plan Risk Responses - A risk management plan is prepared based on the outcome of a questionaries-based survey in the construction project.

Perform Qualitative \& Quantitative Risk Analysis-After the risk management plan is laid out, we have to identify risk $\&$ rank according to its priority based on the questionnaire survey in the construction projects. The major risk is identified by performing quantitative and qualitative methods like probability branching, primavera risk analysis tools, etc

Implement Risk Responses-It is the process of executing risk responses using various tools and techniques.

Monitor Risks-The above-identified risk are monitored throughout the project for project managers to run project effectively

\subsection{Risk Approach}

Below are the various risk approaches

Risk Avoidance- Risk avoidance is to get rid of the risk by using previous risk analysis from several completed projects.

Risk Reduction- While planning and designing the project we can brainstorm with a client, architect, project managers, structural designer and reduce the risk before the implementation of the project

Risk Transfer- Risk can be transferred to the third party and transfer the ownership to bear the risk by agreement, warranties \& bonds.

Risk Acceptance- Risk acceptance involves embracing the risk. It can be categorized into active and passive Active: Risk can be predicted and prompt action can be taken by management using time and resources so the risk could be mitigated in the initial stage. Passive: This involves a realization of risk after its occurrence. So, we have to accept the risk, bear the loss and solve accordingly.

\section{LITERATURE REVIEW}

\subsection{Literature Study - National Scenario}

Patel Ankit Mahendra, (2013) Risks have a vital impact on construction comes in a phrase of it. Construction comes that area unit tangled in nature, unpredictability \& risks from a different origin. After the risk is found, assessment is performed qualitatively and quantitatively, response with an appropriate technique for handling risks, so management the risks by examination. It is based on risk management practices and provides the best solutions 
A. Suchith Reddy (2015) has inspected risk and its outcome within the construction field and also the process needed for risk management. The outcome of risk is evaluated in the project and the various tools and strategies applied to manage risk in the construction industry.

Chaitali S. Pawar et al. (2015) The risks in the construction industry have been predictable as a vital management procedure to accomplish the project goal in terms of price, time, scope, and quality. Qualitative risk analysis finds out the importance of trot elaborate risks. It provides a quick and distinct illustration of risk. the chance assessment matrix is framed in line with the collision of risks on consumer \& contractor as a result of each section of the contract could also be re-modulated study recommended a couple of ideas to moderate construction project risks.

Srinivas. K (2015) examined a study on risk assessment ranking reports on infrastructure enhancements within the Indian industry. Risk management may be a proactive technique to get the complete edges of the necessary programs that are initiated in each enterprise. The appliance of higher risk management practices aims to attain a full profit. The analysis was performed out for the chosen project by considering half-dozen doable risks in numerous phases of the project, that square measure capable of inflicting AN unnecessary lag within the completion of the project. various factors of the intense risks listed and supported the feedback obtained from the participants and also the RSI was firm for every of the 35 risk factors and a building project is subjected to risk and mitigating steps have to be compelled to be taken to scale back the chance impact to a manageable level if the threats tend to be uncontrollable.

Danish Ali et al. (2016) Once risk is located, a quantitative or qualitative assessment of risk is carried out and the best process to handle risk is chosen. A survey is conducted among the person to develop and mitigate risk

S M Abdul Mannan Hussain et al. (2017) Economic process and socio-economic development square measure are significantly necessary for developing countries. Construction comes square measure started in complex and vigorous environments leading to high unpredictability and risk. Project management literature describes extensively acknowledged risk management techniques, that is from four stages: risk identification, risk estimation, risk response designing and execution, risk management.

Mayank Kumar Singh et.al, (2017) Construction industry is susceptible to risk creating an environment of high unreliability and risk. The business is in the endangerment of various industrial and trading risks. The objective of this analysis is to spot significant ongoing risks and uncertainties among the business through literature survey and idents to form a foundation for forthcoming study for the development of a risk management structure to be acquired by stakeholder

Ms. M Sivagami et.al, (2019) virtually each construction project faces some variety of risks throughout several stages. This affects project purpose in terms of your time, cost, quality, and performance as an entire or partially. there's an instantaneous relationship between procurance sort and risk management during a construction project. This paper deals with this relationship in some procurance choices and relies on form survey and interviews from authors

S. Keerthana et.al, (2019) Construction comes area unit started very vital and dynamic setting which ends up during a bigger variety of uncertainties and risks, that demand time constraints. currently day's construction industries area unit ever-changing their state of affairs by every day basis supported their wants and uncertainties that prevail everywhere the globe. From the previous works of literature, the various risk is taken into consideration. SCENARIO

\subsection{Literature Study - International Scenario}

Ekaterina Osipova (2008) The analysis focuses to consider risk management within the different procurement options. The study has addressed various construction projects performed 
in Sverige and it includes a form survey and a series of interrogation with different stakeholders in the construction field. The outcomes of it show a scarcity of a repetitive approach to risk management, which may be a deficiency in current procurement practices.

Nerija Banaitiene et al. (2012) The construction industries are affecting unemployment and monetary loss. This has led to a change in the behavior of the clients and construction companies. This leads to upgrade quality, performance, and reduce price, and the need for project methodologies and management that can constructively manage project risk. This paper illustrates the research in Lithuania's construction projects that aim to analyze the risk analysis and risk management process

Shahid IQBAL et al. (2014). This research is established on the discovery of a questionnaire-based survey on risk management in construction in West Pakistan. 2 kinds of risk management methods are analyzed preventive approach and remedial approach of risk in the project. The study uncovers that monetary problems, a mishap on-site, and faulty style area units are major risks. The study facilitates the preparation of a schedule and smart coordination to facilitate managers to target vital areas in the project and reduce risks

Agnieszka Dziadosz et al. (2015) This analysis enhances the decision-making process and avoids project mistreatment from a Multi-Aspects perspective. It provides 3 different methods. This technique is established on the extended perspicacity of a choice maker. The investigation was completed on the method, that finds the kind of utilized information so it affects the standard outcome. The analysis issues, that area unit the canvas of application of the mentioned process doesn't seem to be reciprocally interconnected. They gift different features of alternatives of the investment method.

Pawel Szymanski (2017) Effective risk management will involve discovery and categorization of risk and very extensive analysis. The Discovery of project risks based on the project critical and its diversity could influence the project and estimating the chance of its incidence on the project. These circumstances are often classified into 3 categories: assurance, uncertainty, and risk They are 3 types of investors: risk preference, neutrality toward risk, and pure risk aversion and its measure. The conclusion of risk discovery and analysis of the project is a series of events showing the cause and the instance of an incident, and evaluate the impact on the atmosphere

Zakari Tsigaa et al. (2017) Proactive management of risk assist to escalate the success rate and deduction of price. The paper introduces a greenhorn tool for implementing the possibility management practices incomes. The tool allows the member to know a project, and to investigate risks during a project design using a different procedure like risk manifestation and town technique

\subsection{Summary of Literature Review}

Table 1

\begin{tabular}{|l|l|l|l|l|l|}
\hline $\begin{array}{l}\text { SI. } \\
\text { No. }\end{array}$ & \multicolumn{1}{|c|}{ TOPIC } & \multicolumn{1}{|c|}{ AUTHOR } & \multicolumn{1}{|c|}{$\begin{array}{c}\text { JOURNAL/ } \\
\text { BOOK }\end{array}$} & \multicolumn{1}{|c|}{ YEAR } & \multicolumn{1}{c|}{ REMARK } \\
\hline 1. & $\begin{array}{l}\text { A Study of Risk } \\
\text { Management } \\
\text { Techniques for } \\
\text { Construction } \\
\text { Projects in } \\
\text { Developing } \\
\text { Countries }\end{array}$ & $\begin{array}{l}\text { Patel Ankit } \\
\text { Mahendra, } \\
\text { Jayeshkumar R. } \\
\text { Pitroda, J. J. } \\
\text { Bhavsar }\end{array}$ & $\begin{array}{l}\text { International } \\
\text { Journal of } \\
\text { Innovative } \\
\text { Technology and } \\
\text { Exploring } \\
\text { Engineering }\end{array}$ & $\begin{array}{l}\text { October } \\
2013\end{array}$ & $\begin{array}{l}\text { This study us to apply } \\
\text { the risk management technique which } \\
\text { includes well - documented procedures and } \\
\text { it helps us to resolve all types of hazards } \\
\text { most likely to occur in any construction } \\
\text { project }\end{array}$ \\
\hline $\begin{array}{l}\text { 2. } \\
\text { Risk Management } \\
\text { in Construction } \\
\text { Project }\end{array}$ & $\begin{array}{l}\text { Shahid Iqbal, } \\
\text { Rafiq M. } \\
\text { Choudry, Klaus }\end{array}$ & $\begin{array}{l}\text { Technological and } \\
\text { economic }\end{array}$ & $\begin{array}{l}\text { November } \\
2014\end{array}$ & $\begin{array}{l}\text { The paper aims to know about different } \\
\text { construction practitioners, toward different } \\
\text { types of risk and management plan }\end{array}$ \\
\hline
\end{tabular}




\begin{tabular}{|c|c|c|c|c|c|}
\hline & & \begin{tabular}{|l|} 
Holsechmac, \\
Ahsan ALId \\
,Jolanta Tamostin
\end{tabular} & $\begin{array}{l}\text { development of } \\
\text { Economy }\end{array}$ & & $\begin{array}{l}\text { accordingly. In the paper, we came to know } \\
\text { the most effective techniques in } \\
\text { preventing/mitigating different types of risk. }\end{array}$ \\
\hline 3. & $\begin{array}{l}\text { Risk Management } \\
\text { in Construction } \\
\text { Industry - A Case } \\
\text { Study }\end{array}$ & A. Suchith Reddy & $\begin{array}{l}\text { International } \\
\text { Journal of } \\
\text { Innovative } \\
\text { Research in } \\
\text { Science, } \\
\text { Engineering and } \\
\text { Technology }\end{array}$ & $\begin{array}{l}\text { October } \\
2015\end{array}$ & $\begin{array}{l}\text { A survey is conducted on the following } \\
\text { aspects and its Identify, characterize, and risk } \\
\text { involved in the construction industry Assess } \\
\text { the vulnerability of critical assets to specific } \\
\text { threats. Determine the risk (i.e. the expected } \\
\text { consequences of specific types of attacks on } \\
\text { specific assets, identifies ways to reduce } \\
\text { those risks and risk is Prioritize to reduce } \\
\text { risk measures based on a strategy }\end{array}$ \\
\hline 4. & $\begin{array}{l}\text { Risk } \\
\text { Management } \\
\text { Strategies in } \\
\text { Construction } \\
\text { Companies in } \\
\text { India }\end{array}$ & $\begin{array}{l}\text { Danish Ali , } \\
\text { Alvin Harison }\end{array}$ & \begin{tabular}{|l|} 
IJIRST- \\
International \\
Journal for \\
Innovative \\
Research in \\
Science \& \\
Technology
\end{tabular} & $\begin{array}{l}\text { March } \\
2016\end{array}$ & $\begin{array}{l}\text { The paper aims to know about various } \\
\text { risks in the construction industry and a } \\
\text { survey is taken in many construction } \\
\text { industries. Some risk management plans are } \\
\text { suggested to overcome to provide a risk-free } \\
\text { environment. Its help the managers, } \\
\text { Engineers, Architects, and stakeholders to } \\
\text { consider risk and plan accordingly to } \\
\text { overcome from cost and schedule of projects }\end{array}$ \\
\hline 5. & $\begin{array}{l}\text { Risk } \\
\text { Management in } \\
\text { Construction } \\
\text { Project As Per } \\
\text { Indian Scenario }\end{array}$ & \begin{tabular}{|l|} 
Mayank Kumar \\
Singh, Shumank \\
Deep, Rajeev \\
Banerjee
\end{tabular} & \begin{tabular}{|l|} 
International \\
Journal of Civil \\
Engineering and \\
Technology
\end{tabular} & $\begin{array}{l}\text { March } \\
2017\end{array}$ & $\begin{array}{l}\text { Construction industry is highly risk } \\
\text { prone, with complex and dynamic project } \\
\text { environments creating an atmosphere of } \\
\text { high uncertainty and risk. The industry is } \\
\text { vulnerable to various technical and } \\
\text { business risks. Thus, the people working in } \\
\text { the industry bear various failures, such as, } \\
\text { failure of abiding by quality and } \\
\text { operational requirements, cost overruns } \\
\text { and uncertain delays in project completion. } \\
\text { It can be said that an effective systems of } \\
\text { risk assessment management for } \\
\text { construction industry }\end{array}$ \\
\hline 6. & $\begin{array}{l}\text { Risk } \\
\text { management in } \\
\text { construction } \\
\text { projects }\end{array}$ & $\begin{array}{l}\text { Pawel } \\
\text { Szymanski }\end{array}$ & $\begin{array}{l}\text { 2nd International } \\
\text { Joint Conference } \\
\text { on Innovative } \\
\text { Solutions in } \\
\text { Construction } \\
\text { Engineering and } \\
\text { Management: }\end{array}$ & April 2017 & $\begin{array}{l}\text { From the study risk management } \\
\text { should be identified. The management } \\
\text { should be based on checking the maximum } \\
\text { benefits of these decisions, using all the } \\
\text { tools of mathematical and analytical. } \\
\text { Detailed analysis, will account all aspects } \\
\text { of escorts, including even stakeholder } \\
\text { analysis will allow us to effectively risk } \\
\text { manage what the future will translate into } \\
\text { benefits for our project }\end{array}$ \\
\hline
\end{tabular}

Inference: From table 2.4 Risk management is needful in many industries, especially in the construction industry. Many industries are not conscious of the risk management plan and it should be implemented in many industries Risk discovery and management techniques are scarcely used in the construction industry. From the literature study, we understand that risk management practices are done based on questionaries survey in the construction industry. Based on Questionaries survey analysis result scoring matrix is done or using probabilistic branching to avoid risk more efficiently.

\section{CONCLUSION}

This paper, help us to understand the basic concepts of risk management. From the literature study, we understand many tools and methodologies are used for risk management. Risk management helps the construction industry to forecast from schedule and cost overrun in projects. Some of the risks we have discovered are the risk of bad quality material, inaccurate 
estimation of quantities work, cost overrun, poor competence \& productivity of labor, poor coordination with subcontractor, poor performance of sub-contractor, and inadequacy of insurance. Through the analysis, we understand that weather and natural disaster plays the major role of risk in the construction industry which affect the schedule and cost in the project. In further research, we try to discover risk ranking and scrutinize risk-related reliability for clients, architects, and contractors to supervise risks efficiently and we will be laying out a risk management plan using primavera risk analysis software for project managers to work more productively.

\section{REFRENCES}

[1] Shahid Iqbal, Rafiq M. Choudry, Klaus Holsechmac, Ahsan ALId, Jolanta Tamostin, November 2014 "Risk Management in Construction Project", Technological and economic development of Economy Volume 21(1): 65-78.

[2] Danish Ali, Alvin Harison, March 2016, "Risk Management Strategies in Construction Companies in India", IJIRST-International Journal for Innovative Research in Science \& Technology| Volume 2 | Issue 10

[3] Suchith Reddy, October 2015, "Risk Management in Construction Industry - A Case Study", International Journal of Innovative Research in Science, Engineering and Technology Vol 4, Issue 10

[4] Pawel Szymanski, April 2017 "Risk management in construction projects", 2nd International Joint Conference on Innovative Solutions in Construction Engineering and Management:

[5] Patel Ankit Mahendra, Jayeshkumar R. Pitroda, J. J. Bhavsar, October 2013 “A Study of Risk Management Techniques for Construction Projects in Developing Countries ", International Journal of Innovative Technology and Exploring Engineering (IJITEE) Volume-3, Issue-5

[6] Mayank Kumar Singh, Shumank Deep, Rajeev Banerjee, March 2017," Risk Management in Construction Project as Per Indian Scenario", International Journal of Civil Engineering and Technology (IJCIET) Volume 8, Issue 3

[7] Agnieszka Dziadosza Mariusz Rejment,2015," Risk analysis in construction project - chosen methods", Operational Research in Sustainable Development and Civil Engineering - meeting of EURO working group and 15th German-Lithuanian-Polish colloquium (ORSDCE 2015).

[8] S. Keerthana, T. Pradeep, December 2019," Constructability Risk Assessment in Construction Projects", International Journal of Engineering and Advanced Technology (IJEAT) ISSN: 2249 - 8958, Volume-9 Issue-2,

[9] Terje Aven, December 2015," Risk assessment and risk management: Review of recent advances on their foundation", European Journal of Operational Research

[10] Roque Rabechini Junior, Marly Monteiro de Carvalho," Understanding the Impact of Project Risk Management on Project Performance: An Empirical Study", Journal of Technology Management \& Innovation

[11] Ennouri W, 2013," Risks Management: New Literature Review", Polish Journal of Management Studies"

[12] Philip Bromiley, Michael McShane, Anil Nair, Elzotbek Rustambekov, August 2015," Enterprise Risk Management: Review, Critique, and Research Directions", Long Range Planning Volume 48, Issue 4, Pages 265-276

[13] M Sivagami, Sarath, April 2019," Risk Management in Construction Projects with Respect to Different Procument Option", International Research Journal of Engineering and Technology (IRJET) Volume: 06 Issue: 04 
[14] M.G.Bhandari, Dr. P.G.Gayakwad, January 2014," Management of Risk in Construction Projects in Maharashtra", International Journal of Engineering Science Invention ISSN (Online): 2319 - 6734, ISSN (Print): 2319 - 6726 Volume 3 Issue 1 PP.14-17

[15] Chaitali S. Pawar, Suman S. Jain, Jalinder R. Patil, April 2015, "Risk Management in Infrastructure Projects in India", International Journal of Innovative Research in Advanced Engineering (IJIRAE) ISSN: 2349-2163 Issue 4, Volume 2

\section{AUTHORS PROFILE}
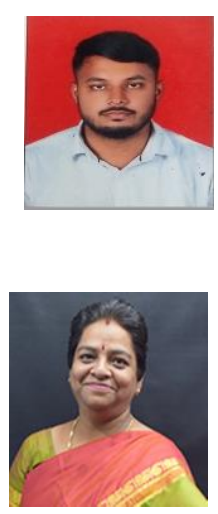

Moinuddin $\mathbf{H}$ is currently pursuing his M.Tech. Degree in Construction Engineering and Project Management in the B.S.A. Crescent Institute of Science and Technology, Vandalur, Chennai. He has completed B.Tech. degree in Civil Engineering from Bharath University, Selaiyur, Chennai.

K. Yogeswari is currently working as an Associate Professor in the Department of Civil Engineering in B.S.A. Crescent Institute of Science and Technology, Vandalur, Chennai. She did her Ph.D. in Sustainable planning in B.S.A. Crescent Institute of Science and Technology, Vandalur, Chennai. She has completed her B.Tech in Civil Engineering and Masters in Town Planning from, School of planning, Anna University. Till date, she has presented in six international conferences and published papers in eight Scopus indexed journals. 